\section{GAMBLING AND THE U.S. IMMIGRATION LAWS}

\section{ROBERT M. JARVIS}

Robert M. Jarvis is a professor of law at Nova Southeastern University in Fort Lauderdale, Florida, USA, and a member of the Editorial Board of Gaming Law Review. The research for this article closed on November 1, 2020.

Keywords: citizenship, deportation, gambling, immigration, naturalization

DOI: $10.1089 / \mathrm{glr} 2.2020 .0027$ (C) Mary Ann Liebert, Inc.

${ }^{1}$ See, e.g., Erica Marshall and Debi LaPlante, Disordered Gambling, in ENCyclopedia of Immigrant Health 565 (San Loue and Martha Sajatovic eds. 2012); Serena M. King et al., Gambling, Substance Use, and Help-Seeking Attitudes in a Community-Based Sample of Lao Refugees, Immigrants, and U.S.-Born Citizens, 51 Prof'l Psychol.: Res. \& Prac. 51 (2020); Mary Keovisai and Wooksoo Kim, "It's Not Officially Gambling": Gambling Perceptions and Behaviors Among Older Chinese Immigrants, 35 J. Gambling Stud. 1317 (2019); Natale Canale et al., A Large-Scale National Study of Gambling Severity Among Immigrant and NonImmigrant Adolescents: The Role of the Family, 66 Addictive BeHaviors 125 (2017); Alyssa N. Wilson et al., Gambling Prevalence Rates Among Immigrants: A Multigenerational Examination, 42 AdDictive Behaviors 79 (2015); Grant N. Marshall et al., Prevalence and Correlates of Lifetime Disordered Gambling in Cambodian Refugees Residing in Long Beach, CA, 11 J. Immigr. \& Minority Health 35 (2009); Sandra L. Momper et al., The Prevalence and Types of Gambling Among Undocumented Mexican Immigrants in New York City, 25 J. GAMBLING Stud. 49 (2009); Nancy M. Petry et al., Gambling Participation and Problems Among South East Asian Refugees to the United States, 54 PsYchiATRIC Svcs. 1142 (2003); Tamika Harvey and Nyamal Tutdeal, The Influence of Gambling on the Immigrant and Refugee Community, 17 Th INTERNATIONAL CONFERENCE ON GAMBLING \& RISK TAKING, May 29, 2019, at https://digitalscholarship.unlv.edu/ gaming_institute/2019/May29/2/

${ }^{2}$ These consequences, of course, are in addition to any criminal sentence that may be imposed for the underlying gambling offense:

On July 22, 2008, Abid Ghani pled guilty to a single-count tenth superseding information. The information charged that between November 2006 and February 2007, the defendant, together with another, having knowledge of the commission of a felony involving the operation of an illegal gambling business in violation of 18 U.S.C. $\S 1955$, concealed and did not make known the illegal business.

Ghani was sentenced on November 25, 2008. . . Ghani is a citizen of Pakistan; at the sentencing hearing he waived his right to have his consulate informed of the charges against him and indicated an understanding of the potential immigration consequences of this conviction.

United States v. Ghani, 2008 WL 5459184, at*1 (E.D.N.Y. 2008). See also Chai v Att'y Gen. U.S., 440 F. App'x 152, 154 (3d Cir. 2011) ("While she was living in the United States, Chai developed a gambling addiction. To facilitate this addiction, she engaged in illegal behavior. On March 10, 2006, Chai pleaded guilty to, and was convicted of, one count of theft by deception and one count of theft by unlawful taking. She was sentenced to three years' imprisonment on each count, the terms to run concurrently. On June 20, 2006, Chai was charged with removability under 8 U.S.C. $\$ 1227(\mathrm{a})(2)(\mathrm{A})(\mathrm{ii})$, as an alien convicted of two crimes involving moral turpitude not arising out of a single scheme of criminal conduct, and under 8 U.S.C. $\S 1227$ (a)(2)(A)(iii), as an alien convicted of an aggravated felony.”); Shah v. Wolf, 2020 WL 4456530, at *1 (N.D. Tex.), report and recommendation adopted, 2020 WL 4437484 (N.D. Tex. 2020) (Pakistani citizen ordered deported after being convicted of various crimes, including "possession of a gambling device in violation of [Texas Penal Code] 47.06[.]").

\section{INTRODUCTION}

A

$\mathrm{s}$ has been pointed out elsewhere, immigrants are particularly likely to gamble, either for cultural reasons or because of the stress caused by trying to assimilate. ${ }^{1}$ Under the immigration laws of the United States, however, non-citizens who engage in illegal gambling activities can be denied admission into the country; can be deported; can have their applications for citizenship rejected; and can be denaturalized (i.e., stripped of their U.S. citizenship). ${ }^{2}$ More than one client has gotten into trouble because his or her lawyer did not know about these provisions. ${ }^{3}$ To be fair, however, almost nothing has been written

A non-citizen ordinarily is deported after serving his or her sentence. If supervised release (i.e., parole) is made part of the sentence, "the court may provide, as a condition of supervised release, that [the defendant] be deported and remain outside the United States, and may order that [he or she] be delivered to a duly authorized immigration official for such deportation." 18 U.S.C. $\S 3583$ (d). For examples of such orders, see United States v. Hagay, 2017 WL 5569796, at*4 (E.D. Cal. 2017) (under 95 of "Special Conditions of Supervision"); United States v. Ibarra-Luna, 2009 WL 1181214, at*5 (E.D. Tex. 2009). See also United States v. Seng Chen Yong, 2017 WL 44944, at *2 (D. Nev. 2017) (approving plea deal under which defendant agreed to plead guilty to being an accessory after the fact to an unlawful sports betting operation and further agreed to "a sentence of five years of unsupervised probation[,] a fine of $\$ 100,000$ [, and to] depart the country immediately and not return for five years.") (footnote omitted), aff'd, 926 F.3d 582 (9th Cir. 2019).

At one time, federal judges imposing a criminal sentence could ask immigration officials to forego deportation. This option no longer exists. See United States v. Stavroulakis, 952 F.2d 686, 697 (2d Cir. 1992).

${ }^{3}$ In Alam v. United States, 630 F. Supp. 2d 647 (W.D.N.C. 2009), for example, a lawyer allowed his Pakistani client to plead guilty to operating an illegal gambling business. When the client later discovered that this plea meant that he could be deported, he moved to have his conviction and sentence vacated. In granting his request, the court wrote:

Counsel's advice regarding the immigration consequences of petitioner's plea was undeniably grossly inaccurate, given that the governing statute- $\S$ 1101(a)(43)(J) - explicitly enumerates a $\S 1955$ conviction as an "aggravated felony" requiring removal. Accordingly, Counsel's advice that a $\S$ 1955 violation is not an "aggravated felony" requiring petitioner's removal clearly fell below an objective standard of reasonableness; indeed, the plain language of the applicable immigration statutes compels the conclusion that Counsel grossly misinformed petitioner on this subject. . .

$[\mathrm{P}]$ etitioner has also demonstrated that he suffered prejudice as a result of Counsel's errors. More specifically, petitioner's affidavit avers - crediblythat he would not have pled guilty absent Counsel's assurances that a $§ 1955$ conviction would not lead to petitioner's removal. Nor is there any reason to doubt this averment, as the record reflects (i) that petitioner has resided in the United States for more than twenty-five years; (ii) that petitioner's wife is a permanent legal resident; (iii) that petitioner's children are native-born U.S. citizens; and (iv) that petitioner has built a successful business in the United States distinct from any illegal gambling. These circumstances make it clear that petitioner would not want to return to Pakistan, a currently unstable country with which he apparently has few ties. And it follows a fortiori that if petitioner would not have pled absent Counsel's erroneous pre-plea advice, petitioner similarly would have sought to withdraw his plea in the absence of Counsel's erroneous assurances that Counsel could convince the government to halt removal after sentencing. Thus, petitioner has demonstrated a reasonable probability that, but for Counsel's constitutionally ineffective assistance, he would not have pled guilty and would have insisted on going to trial. Accordingly, the petition must be granted and petitioner's conviction and sentence vacated.

Id. at 652-54 (footnotes omitted). For another such case, see United States v. Sun Hwang, 658 F. App'x 874 (9th Cir. 2016) (criminal lawyer who obtained opinions 


\section{about them. ${ }^{4}$ Accordingly, this article provides a much- needed primer. ${ }^{5}$ Before proceeding, one important point should be made. Contrary to popular belief, nothing pre-}

from two different immigration lawyers, one stating that the client would be subject to removal if she pled guilty to a gambling offense and the other taking the opposite position, did not meet his constitutional obligations by simply giving the client both opinions with no advice as to which one was correct).

In Matter of A-D-, 2017 WL 5714082 (A.A.O. 2017), however, the applicant's claim of ineffective assistance of counsel was rejected:

The record reflects the following criminal history:

- In 2005, the Applicant was convicted after pleading guilty to assault of a family member, which is a class A misdemeanor under section 22.01 of the Texas Penal Code. She was sentenced to six days in jail and a $\$ 100$ fine.

- In 2014, the Applicant was convicted after pleading guilty to possession of gambling device, equipment, or paraphernalia, which is a class A misdemeanor under section 47.06 of the Texas Penal Code. She was sentenced to three days in jail. . . .

The Applicant asserts there were mitigating circumstances underlying each of her convictions . . . . First, she states that she pled guilty to the charges based on her defense attorney's advice that these were minor offenses that would not affect her immigration status. . .

Unfortunately, we are unable to exclude the Applicant's convictions, as she has not shown that the convictions have been vacated or overturned. Collateral attacks upon a conviction "do not operate to negate the finality of [the] conviction unless and until the conviction is overturned." Matter of Madrigal-Calvo, 21 I\&N Dec. 323, 327 (BIA 1996).

The Applicant claims that she suffered ineffective assistance of counsel for both charges, but she has not provided evidence that either conviction has been vacated based on a defect in the proceedings. See Matter of Adamiak, 23 I. \& N. Dec. 878, 881 (BIA 2006) (holding that a conviction vacated because of a defect in the underlying criminal proceedings, i.e., the failure of the court to advise of the possible immigration consequences of a guilty plea, should be recognized for immigration purposes.). . .

$I d$. at $* 2$.

The same result was reached in In re Applicant, 2013 WL 3903472 (A.A.O. 2013):

In response to notices dated October 20, 2011 and February 21, 2012, which requested the applicant to submit certified judgment and conviction documents from the courts for all arrests, the applicant submitted court documentation in Case number 11-2011-CF-001001-CXXX-XX from the Circuit Court, Twentieth Judicial Circuit, in and for Collier County, Florida. The court documentation reflects that on May 5, 2011, the applicant was arrested and charged with establish gambling place keep house for, resist officer obstruct without violence and lottery - operating set up promote conduct for money. On June 6, 2011, the charges were amended to indicate lotteryplaying possess ticket, a violation of Florida Status 849.09(1)(h), a first degree misdemeanor, and Florida Statute 849.09(1)(d);777.011, lottery - aid setting up, promoting, or conducting for money, a third degree felony. On January 5, 2012, the applicant pled no contest to violating Florida Statute 849.09(1)(d); 777.011. Adjudication of guilt was withheld and the applicant was placed on probation for 18 months and ordered to pay court costs Counsel's statements have been considered; however, no evidence has been provided on appeal to support his assertion that the applicant had not been advised of the possible immigration consequences of a plea by either his counsel or the trial court. The assertion of counsel does not constitute evidence. Matter of Laureano, 19 I\&N Dec. 1, 3 (BIA 1983); Matter of Obaigbena, 19 I\&N Dec. 533, 534 (BIA 1988); Matter of Ramirez-Sanchez, 17 I\&N Dec. 503, 506 (BIA 1980). The AAO concludes that the felony conviction continues to effect immigration consequences. Furthermore, the adjudication of an appeal will not be held in abeyance while an applicant is seeking post-conviction relief.

$I d$. at $* 2$.

${ }^{4}$ No previous work specifically focusing on the immigration consequences of gambling crimes has been found. Instead, commentators simply have mentioned in passing that non-citizens can get into trouble for illegal gambling. See, e.g., Susan L. Pilcher, Assessing Collateral Immigration Consequences of Criminal Justice Decisionmaking When the Defendant Is an Alien, 8 Fed. Sent. Rer. 279, 280 (1996) vents an undocumented immigrant from claiming a gaming prize. Doing so, however, may bring the player to the attention of the immigration authorities.

("[C]ertain gambling activities will temporarily preclude findings of good moral character, even absent criminal charge or conviction."); Maryellen Fullerton and Noah Kinigstein, Strategies for Ameliorating the Immigration Consequences of Criminal Convictions: A Guide for Defense Attorneys, 23 Am. CRIM. L. Rev. 425, 436 (1986) ("Sixth, regulatory violations are generally not crimes of moral turpitude. Gambling and immigration violations are examples of regulatory violations.") (footnotes omitted); Patricia J. Freshwater, Note, The Obligation of NonRefoulement Under the Convention Against Torture: When Has a Foreign Government Acquiesced in the Torture of Its Citizens?, 19 Geo. Immigr. L. J. 585, 589 n.27 (2005) ("Whereas the term 'aggravated felony' may sound as if it includes only the most serious violent crimes, under the definition provided by the Immigration and Nationality Act, even theft offenses with a penalty of more than one year in prison, illegal gambling, and fraud are generally considered aggravated felonies.").

The current gap is particularly evident when one examines Mary E. Kramer's otherwise excellent treatise Immigration Consequences of Criminal Activity: A Guide to Representing Foreign-Born Defendants (8th ed. 2019). Kramer's entire discussion of the subject consists of the following sentence: "The abbreviated list below contains the aggravated felony offenses under the INA, most of which are discussed in greater detail throughout the chapter. . . (J) Certain racketeering and gambling offenses, where a term of imprisonment of at least one year may be imposed[.]" Id. at 349-50.

${ }^{5}$ Cases such as United States v. Ong, 541 F.2d 331 (2d Cir. 1976), cert. denied, 429 U.S. 1075 (1977), are beyond the scope of this article. In Ong, the operators of multiple illegal gambling houses were found guilty of trying to bribe local immigration officers. For similar cases, see United States v. Cheng, 763 F. App'x 85 (2d Cir. 2019) (defendant sentenced to 68 months in prison for using extortion to enforce gambling debts was not entitled to a credit for the six months he spent in immigration custody); Qian Jin Lin v. Anderson, 2013 WL 3776249 (S.D.N.Y. 2013) (dismissing with prejudice plaintiff's claim that immigration officers wrongly seized $\$ 5,600$ from her during a raid of a suspected illegal betting parlor). This article also omits the many cases in which an applicant has cited his or her spouse's gambling as part of an effort to obtain "battered alien" status. See, e.g., In re Self-Petitioner, 2014 WL 5430939 (A.A.O. 2014). For a case in which an applicant instead sought to protect her spouse, see In re Application, 2007 WL 5338236 (A.A.O. 2007). Among other reasons, the applicant asked not to be sent back to India because her husband, having worked in the U.S. gambling industry, would find it difficult to get a job if he joined her:

Counsel asserts that, if [husband] is honest in regard to his employment history with a casino, a significant number of employers will not consider him because gambling is illegal and considered taboo in India. However, there is no evidence in the record that [husband] would suffer any consequences as a result of his employment in the U.S. gaming industry.

$I d$. at *6. For a case in which a woman fled her homeland to avoid a forced marriage, which had been arranged to pay off her mother's gambling debts, see Ying Lin v. U.S. Att'y Gen., 319 F. App'x 777 (11th Cir. 2009).

Although it is not an immigration case, Huerta-Orosco v. Cosgrove, 979 F. Supp. $2 \mathrm{~d} 974$ (N.D. Iowa 2013), is quite interesting. In it, the court granted the plaintiff's request for permission to file an amended complaint based on the following facts:

Huerta-Orosco claims that on October 31, 2000, he was "a non-English speaking undocumented illiterate Mexican National" and that he won the sum of $\$ 1,019,000.19$ while gambling on a riverboat. . . He further contends he was concerned that he could not claim his winnings because of his immigration status and that he would be turned in for deportation if he attempted to do so.

To resolve this dilemma, Huerta-Orosco allegedly sought the help of . . . Pamela Rosales and Randy Verbeski. While the new complaint does not describe Huerta-Orosco's relationship with them, he alleges that they agreed to help him claim the money and ultimately made the claim under Rosales' name. He alleges that [the riverboat] paid Rosales an advance of about $\$ 36,750$, which she delivered to Huerta-Orosco.

Huerta-Orosco next alleges that at the direction of Rosales and Verbeski, he retained "Joe Cosgrove, aka Francis 'Joe' Cosgrove, Frank Cosgrove and/or the Cosgrove Law Firm" to recover the remainder of the winnings through Rosales and Verbeski. He alleges that his immigration status and concerns about deportation were explained to "Cosgrove" and that "Cosgrove" agreed 


\section{LEGAL FRAMEWORK}

The first reported U.S. case to discuss the relationship between gambling and immigration appears to be In re Ah Fong. ${ }^{6}$ In 1874, while riding circuit in California, U.S. Supreme Court Justice Stephen J. Field opined:

Where the evil apprehended by the state from the ingress of foreigners is that such foreigners will disregard the laws of the state, and thus be injurious to its peace, the remedy lies in the more vigorous enforcement of the laws, not in the exclusion of the parties. Gambling is considered by most states to be injurious to the morals of their people, and is made a public offense. It would hardly be considered as a legitimate exercise of the police power of the states to prevent a foreigner who had been a gambler in his own country from landing in ours. If, after landing, he pursues his former

to assist. He alleges that he paid Cosgrove an advance of $\$ 5000$ and agreed to pay an additional $\$ 5000$ when the funds were fully recovered.

Next, Huerta-Orosco alleges Cosgrove told him that upon recovery of the full amount, he would deposit the funds into his client trust account and would hold the funds in trust until Huerta-Orosco demanded them. $\mathrm{He}$ contends that Cosgrove drafted a document for that purpose but that HuertaOrosco's name was excluded from the document due to his immigration status. He alleges being told that the agreement "was to recover the $\$ 1,000,000$ for him three ways through Cosgrove, Rosales, and Verbeski which Cosgrove would deposit in [his] client-trust account in Defendant's name as Trustee for Plaintiff's benefit terminable at his will."

Huerta-Orosco next alleges that he was incarcerated on federal drug charges twenty days later but was not concerned about his winnings because he had entrusted them to Cosgrove, as his attorney. He claims that over the next five years, he made efforts to contact Cosgrove about the funds but that his calls were not accepted. He then alleges that he wrote to Cosgrove in 2006 about the funds and received letters from both Joe Cosgrove and Frank Cosgrove in which they denied any knowledge of the situation. After that, Huerta-Orosco alleges that he was transferred to another institution, causing him to lose contact information and documents concerning this matter. However, he alleges that he was able to write to Cosgrove again in 2010 to demand the return of his funds and that he filed this action after receiving no response.

Id. at 976-77 (footnote omitted)

L \& L Doc's, L.L.C. v. Florida Div. of Alcoholic Beverages \& Tobacco, 882 So. $2 d$ 512 (Fla. Dist. Ct. App. 2004), review denied, 902 So. 2 d 790 (Fla. 2005), likewise deserves a brief mention. After buying a bar, the purchasers sought to repudiate the contract by arguing that they had been duped by the seller:

A few months after purchasing the restaurant, Latte [one of the two buyers] was arrested and charged by the City of Fort Lauderdale with engaging in gambling. The buyers subsequently defaulted on the note by failing to make the required payments, and did not cure the default. As a result, seller filed suit. Buyers answered the complaint. ... The thrust of their defenses was that seller fraudulently misrepresented material facts relating to the conditions of the business and premises. Specifically, buyers asserted that (1) seller had represented that the slot machines on the premises were a valid source of revenue when he knew that gambling was illegal. . . .

[L]atte asserted that, because he is a recent immigrant to this country from Italy, he was unaware that gambling is illegal in the state of Florida or that the operation being run by Dressel [the seller's president] was illegal. Moreover, because the slot machines were being operated out in the open, Latte never occupation, fine him, and, if he persists in it, imprison him, and the evil will be remedied. ${ }^{7}$

The current immigration laws of the United States appear in Title 8 of the United States Code. ${ }^{8}$ As will be seen, they differ significantly from the approach advocated by Justice Field.

Section 1101 ("Definitions") mentions gambling twice. First, in paragraph (a)(43), it defines the term "aggravated felony" as including:

(J) an offense described in section 1962 of Title 18 [the Racketeer Influenced and Corrupt Organizations (RICO) Act] ... or an offense described in section 1084 [of the Interstate Wire Act of 1961] (if it is a second or subsequent offense) or 1955 [the Illegal Gambling Business Act of 1970] ... for which a sentence of one year imprisonment or more may be imposed[. $]^{9}$

questioned the legality. He first learned that the machines were illegal when the police raided the bar and confiscated the machines.

Id. at 513, 515. See also Park v. Comm'r, 722 F.3d 384 (D.C. Cir. 2013) (foreign gamblers permitted to calculate their gambling winnings and losses in the same manner as U.S. citizens); Jombo v. Comm'r, 398 F.3d 661 (D.C. Cir. 2005) (noncitizen who won New York State Lottery was liable for U.S. taxes, notwithstanding his claim of diplomatic immunity).

${ }^{6} 3$ Sawy. 144 (C.C.D. Cal. 1874).

${ }^{7} I d$. at 217. It should be noted that Justice Field's comment constitutes dicta because the government's reason for excluding the petitioner was its contention that she was a "lewd and debauched wom[a]n" (i.e., a prostitute rather than a gambler). Id. at 214

${ }^{8}$ See 8 U.S.C. $\S \S 1101-1778$. The country's first immigration law was the Naturalization Act of 1790, ch. 3, 1 Stat. 103. Since then, frequent amendments, as well as wholesale revisions, have been made. See 1 Shane Dizon and Pooja Dadhania, Immigration LaW Service $\S \S 1: 2-1: 118$ ( 2 d ed. 2020). The present statutory framework dates to the Immigration and Nationality Act of 1952 (INA), Pub. L. 82414, 66 Stat. 163 .

${ }^{9} 8$ U.S.C. $\S \S 1101(\mathrm{a})(43)(\mathrm{J})$. This wording is the product of changes made by the Antiterrorism and Effective Death Penalty Act of 1996 (AEDPA), Pub. L. No. 104132, 110 Stat. 1214, and the Illegal Immigration Reform and Immigrant Responsibility Act of 1996 (IIRIRA), Pub. L. No. 104-208, 110 Stat. 3009-546:

Enacted in the wake of the 1995 Oklahoma City bombing, AEDPA reflected both popular and legislative determination to deter and punish terrorism. Notwithstanding President Clinton's acknowledgment that the bill "made a number of major, ill-advised changes in our immigration laws having nothing to do with fighting terrorism," he signed the bill into law on April 24, 1996. Section 440(e) of AEDPA added new crimes to be considered aggravated felonies under section 101(a)(43) of the INA. The newly designated aggravated felony crimes included gambling offenses and the transmission of wagering information. . .

A mere six months after the enactment of AEDPA, Congress passed IIRIRA, this time devoting an entire bill solely to immigration law concerns. In contrast to the rather hasty changes wrought by AEDPA, IIRIRA implemented far more calculated, though equally far-reaching, amendments to United States immigration law. These changes included new additions and revisions to the aggravated felony definition. ... Whereas RICO-related and gambling offenses previously were aggravated felonies if they carried a potential sentence of five years or more, IIRIRA . . lowered this to one year. 
Second, in paragraph (f)(4)-(5), it provides:

For the purposes of this chapter-

No person shall be regarded as, or found to be, a person of good moral character who, during the period for which good moral character is required to be established is, or was . . .

(4) one whose income is derived principally from illegal gambling activities; [or]

(5) one who has been convicted of two or more gambling offenses committed during such pe$\operatorname{riod}[.]^{10}$

In addition to these specific provisions, $\S 1101$ contains the following "catch-all" language: "The fact that any person is not within any of the foregoing classes shall not preclude a finding that for other reasons such person is or was not of good moral character."11

Other statutory sections also can come into play a given case. In In re Sadrusi, ${ }^{12}$ for example, the

Terry Coonan, Dolphins Caught in Congressional Fishnets-Immigration Law's New Aggravated Felons, 12 Geo. Immigr. L. J. 589, 600-02 (1998) (footnotes omitted).

${ }^{10} 8$ U.S.C. $\S 1101(f)(4)-(5)$.

${ }^{11} 8$ U.S.C. $§ 1101$. In Torres v. Lynch, 136 S. Ct. 1619 (2016), the Court upheld the catch-all provision and applied it to state crimes not involving interstate commerce. In so ruling, the Court explained that it was rejecting the petitioner's argument because:

Luna's [Torres's preferred last name] view would limit the penultimate sentence's effect in a peculiarly perverse fashion-excluding state and foreign convictions for many of the gravest crimes listed in $\S 1101(\mathrm{a})(43)$, while reaching those convictions for less harmful offenses. Consider some of the state and foreign crimes that would not count as aggravated felonies on Luna's reading because the corresponding federal law has a commerce element: most child pornography offenses, including selling a child for the purpose of manufacturing such material, see $\S 1101(\mathrm{a})(43)(\mathrm{I})$; demanding or receiving a ransom for kidnapping, see $\S 1101(\mathrm{a})(43)(\mathrm{H})$; and possessing a firearm after a felony conviction, see $\S 1101(a)(43)(E)(i i)$. Conversely, the term "aggravated felony" in Luna's world would include state and foreign convictions for such comparatively minor offenses as operating an unlawful gambling business, see $\S 1101(\mathrm{a})(43)(\mathrm{J})$, and possessing a firearm not identified by a serial number, see $\S 1101(\mathrm{a})(43)(\mathrm{E})(\mathrm{iii})$, because Congress chose, for whatever reason, not to use a commerce element when barring that conduct.

Id. at 1628

In United States ex rel. Marcello v. Dist. Dir. I.N.S., New Orleans, La., 634 F.2d 964 (5th Cir.), reh'g denied, 641 F.2d 879 (5th Cir.), cert. denied, 452 U.S. 917 (1981) the Fifth Circuit applied the catch-all provision to a foreign gambler:

Since the respondent served less than 180 days in prison for his 1968 conviction, he avoids the statutory bar to a finding of good moral character contained in section 101(f)(7) of the Act. Since the respondent has not been shown to have derived his income principally from gambling during the last ten years, he also avoids the preclusion contained in section 101(f)(4) of the Act. However, the fact that the respondent's conduct is not within the grounds enumerated by the statute does not prevent us from considering it in respondent was convicted of operating an illegal gambling business in violation of 18 U.S.C. $\S$ 1955. ${ }^{13}$ In upholding his subsequent deportation order, the Board of Immigration Appeals (BIA) ${ }^{14}$ explained: "Notably, the respondent's charge of deportability did not pertain to his conviction at all. Instead, it simply referenced the fact that he had remained in the United States for a time longer than that permitted by the non-immigrant visa he used to obtain his admission." 15

\section{ADMISSION}

Numerous individuals are classified as being ineligible for admission into the United States. ${ }^{16}$ The two categories most relevant for present purposes are: "commercialized vice" and "public charge."

\section{A. Commercialized vice}

A person who seeks to enter the United States to engage in "commercialized vice" is inadmissible. ${ }^{17}$ As making an overall assessment of good moral character. See section 101(f), Immigration and Nationality Act. . . .

The respondent's criminal record covers a span of 38 years, going back to 1930. During at least a portion of this time, the respondent's income was derived from gambling. The respondent's most recent conviction, for a felony, occurred within the ten-year period for which good moral character is required, and he was imprisoned for a period just short of that which would have precluded him from establishing good moral character. On these facts we find no evidence of the type of character reformation that would warrant a finding of good moral character for the statutory period. Consequently, we conclude that the respondent has failed to meet the good moral character requirement of section 244(a)(2) of the Act.

The respondent's application for suspension of deportation under section 244(a)(2) of the Act must be denied both for failure to establish statutory eligibility and in the exercise of discretion. The result reached by the immigration judge was correct. Accordingly, the appeal will be dismissed.

Id. at 979 .

${ }^{12} 2008$ WL 2783052 (B.I.A. 2008)

${ }^{13} I d$. at $* 1$ n. 1 .

${ }^{14}$ The Board of Immigration Appeals (BIA), part of the U.S. Department of Justice, oversees the country's immigration courts. See Dizon AND DADHANIA, supra note 8 , at $\S \S 1: 183-1: 192$. It is just one of the many entities that handle immigration cases. For a list and discussion of other relevant entities, see id. at $\S \S 1: 119-1: 224$. See also infra note 24

${ }^{15}$ Sadrusi, 2008 WL 2783052, at *2 n.2. For another such case, see Rathod v. Barr, 2020 WL 1492790 (W.D. La.), report and recommendation adopted, $2020 \mathrm{WL}$ 1501891 (W.D. La. 2020) (Indian citizen who pleaded guilty to keeping an illegal gambling place ordered removed for overstaying his visitor visa).

${ }^{16}$ See 8 U.S.C. $\S 1182$. Among those barred are child abductors, drug abusers, drunks, genocide participants, Nazis, polygamists, prostitutes, smugglers, spies, and terrorists. See Dizon and Dadhania, supra note 8 , at $\S \S 3: 2-3: 128$.

${ }^{17}$ See 8 U.S.C. $\S 1182$ (a)(2)(D)(iii) ("Any alien who_ _ . . is coming to the United States to engage in any other unlawful commercialized vice, whether or not related to prostitution, is inadmissible."). 
one would expect, commercialized vice has been held to include illegal gambling. ${ }^{18}$

In In re Leong Youk Tong, ${ }^{19}$ a case decided before the statute included the term "commercialized vice," a Chinese merchant who had emigrated to the United States in 1891 took an overseas business trip in 1897. ${ }^{20}$ When he returned to the United States in 1898, he was refused admission and charged with being the owner of a gambling-and-prostitution house. ${ }^{21}$ In upholding this finding, the court wrote:

By the law of August 18, 1894, it is provided as follows:

"In every case where an alien is excluded from admission into the United States under any law or treaty now existing or hereafter made, the decision of the appropriate immigration or customs officers, if adverse to the admission of such alien, shall be final, unless reversed on appeal to the secretary of the treasury."

....

[T] he evidence shows that, after announcing his decision, the collector proceeded to take further evidence, which tended to show that the petitioner was not in reality a merchant, but that he had carried on a pretended business as a merchant as a blind, and with the object of remaining within the United States and giving his attention to other occupations. Whether the evidence was sufficient to sustain that conclusion it is unnecessary to consider.... The testimony which was offered in this case by the petitioner's counsel, and rejected by the collector, was thereafter presented to the secretary of the treasury on the appeal. It follows from the affirmance of the collector's decision by the secretary either that the purport of such evidence was not deemed sufficient to reverse the decision of the collector, or that its exclusion by him was not held erroneous. The petitioner must be remanded to his custody. $^{22}$

The same result has obtained in more recent cases. In In re Applicant, ${ }^{23}$ for example, the Administrative Appeals Office $(\mathrm{AAO})^{24}$ wrote:

The applicant has pled guilty to multiple offenses related to illegal gambling, including: Disorderly Conduct under New York Penal Law § 240.20 [in] 1998 after being charged with Possession of Gambling Records in the 2nd Degree under New York Penal Law $\S$ 225.15 and Promoting Gambling in the 2nd Degree under New York Penal Law $§ 225.05$; Attempted Possession of Gambling Records in the 2nd Degree under New York Penal Law $\S$ 110-225.15 [in] 2006; Possession of Gambling Records in the 2nd Degree under New York Penal Law § 225.15 [in] 2006; and Promoting Gambling in the 2nd Degree under New York Penal Law $\S 225.05$ [in] 2007. Based on this lengthy pattern of engaging in activities related to illegal gambling, the director found that the applicant is seeking admission to the United States "to engage in [an] unlawful commercialized vice," and thus she is inadmissible under section 212(a)(2)(D)(iii) of the Act. . . .
${ }^{18}$ See Matter of B-, 6 I. \& N. Dec. 98 (B.I.A. 1954), where the BIA reasoned:

The statute uses the phrase "unlawful commercialized vice, whether or not related to prostitution." There does not appear to have been any definition given or discussion had as to the meaning of these words by the various congressional committees, or in the debate in Congress. . .

Webster's New International Dictionary, $2 d$ ed. (1940) contains as one of the definitions of the word "commercialize" the following: "specifically to cause to yield pecuniary profit; as, to commercialize vice." Thus, "commercialized gambling" is such gambling as is a source of sure and steady profit (State $v$. Gardner, 92 So. 368, 371, 151 La. 874 (Sup. Ct., 1922)). The word "vice" is defined as "state of being given up to evil conduct or habit; depravity; wickedness; corruption." While the phrase "commercialized vice" has been referred to as "traffic in women for gain," or "immoralities having a mercenary purpose" (Caminetti v. United States, 242 U. S. 470, 484, 497 (1917)), the court there was speaking of the White Slave Traffic Act which relates specifically to prostitution. However, in the provision of law under discussion, the phrase "commercialized vice" is enlarged by the use of the words "whether or not related to prostitution." It was, therefore, clearly intended by Congress that in construing the phrase "commercialized vice," the definition was not to be ejusdem generis with prostitution but was to be given meaning wider in scope.
$I d$. at 101-02 (italics in original).

${ }^{19} 90$ F. 648 (C.C.D. Or. 1898).

${ }^{20} I d$. at 648 .

${ }^{21} I d$. at $648-49$.

${ }^{22} I d$. at 649-50. For a case reaching the opposite result, see Chin Hong v. Nagle, 7 F.2d 609 (9th Cir. 1925) (son could not be denied admission because his father, a Chinese merchant, spent much of his time running an illegal lottery in Monterey). Although the court rested its decision on the fact that the father also ran a legitimate restaurant, it likely was swayed by the fact that the son had no ties to his father's gambling activities.

${ }^{23} 2011$ WL 10878054 (A.A.O. 2011).

${ }^{24}$ The AAO, more formerly known as the Office of Administrative Appeals (OAA) is part of the U.S. Department of Homeland Security (DHS). It is responsible for reviewing visa application denials. See Dizon and DadHANIA, supra note 8, at $\S \S$ $1: 126,1: 154$. 
As noted above, the applicant was convicted of an offense related to her gambling activities on October 7, 1998. She subsequently departed the United States, then reentered on July 18, 2000 in B-2 status and has remained since. The applicant was convicted of three more separate gambling offenses which suggests she intended to return to the United States for the purpose of continuing to reside indefinitely to engage in an unlawful commercialized vice. . . . ${ }^{25}$

In Matter of $A-,{ }^{26}$ the BIA found that there was no credible evidence that the respondent had sought to enter the United States to engage in commercialized vice:

We come now to the fourth charge relating to the alien's participation in commercialized vice. The evidence establishes that from 1929 to 1931 and from 1939 to 1950 , the alien earned his livelihood in illegal activities relating to the sale of liquor, the taking of numbers, and other gambling activities. His income from the operation of his illegal enterprises, in the later years, ran about $\$ 25,000$ a year. He was convicted on several occasions for violation of lottery laws and on one occasion for violation of bootlegging laws. He is charged with being deportable under section 241 (a) (12) of the act of 1952 which makes deportable certain aliens who engaged in "unlawful commercialized vice, whether or not related to prostitution." The charge cannot be sustained. ... .

[T] he record does not establish that the alien herein was coming to the United States to engage in commercialized vice in 1922 and while there is some indication in connection with the alleged entry in 1931 that he reentered to pursue illegal activity in bootlegging[,] narcotics, or counterfeiting, it is not substantial evidence and the fact of entry is not established. The fourth charge will not be sustained. ${ }^{27}$
In United States v. Iqbal, ${ }^{28}$ the government charged that Shahid Iqbal had immigrated to the United States to help his brother, Tariq Majeed, in an illegal gambling operation that the latter had set up in Austin, Texas. ${ }^{29}$ To prove its case before the immigration judge, the government sought to introduce the presentence investigation report (PSR) from Iqbal's criminal case, in which Iqbal had pled guilty to structuring currency transactions to evade U.S. reporting requirements. ${ }^{30}$ When Iqbal objected, the Fifth Circuit, agreeing with the district court, held that the report was admissible:

DHS initiated removal proceedings against Iqbal in October 2008 on the theory Iqbal immigrated to engage in unlawful commercialized vice through Tariq's illegal gambling enterprise. DHS attempted to introduce Iqbal's PSR to demonstrate that Iqbal immigrated to the U.S. to assist in Tariq's gambling operations notwithstanding the district court's contrary finding. . . . During sentencing, Iqbal vigorously contested the inclusion of multiple statements in the PSR, including his participation in Tariq's gambling ring, his knowledge of illegal activity prior to entering the U.S., and the PSR's calculation of the amount of laundered funds. The district court specifically found that Iqbal had no knowledge of Tariq's illegal enterprise before Iqbal entered the U.S. . . .

But the inaccuracies are, in the end, not cause for concern. The sentencing court's rulings favoring Iqbal on PSR objections are matters of public record. The court's redactions eliminated the possibility that other embarrassing or personal information would come to light. These circumstances lead us to conclude the district court did not abuse its discretion in holding that the public interest in disclosure of Iqbal's redacted PSR to the immigration judge outweighed his remaining privacy interest against the dissemination of inaccurate information. ${ }^{31}$

\footnotetext{
${ }^{25}$ Applicant, 2011 WL 10878054, at *2-*3.

${ }^{26} 6$ I. \& N. Dec. 540 (B.I.A. 1954)

${ }^{27} I d$. at 553. For other such cases, see In re Applicant, 2009 WL 5240349, at *3 (A. A.O. 2009) (holding that the applicant's 1995 and 1998 gambling convictions were too remote in time to cause one "to believe that the applicant is now seeking admission to the United States to engage in commercialized vice."); In re Application, 2008 WL 4052573, at *3 (A.A.O. 2008) ("With the case here, the record does not
}

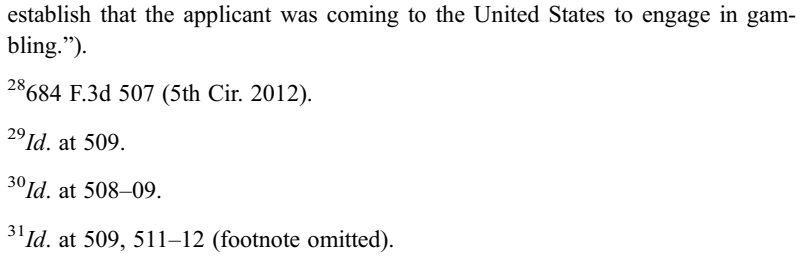




\section{B. Public charge}

A non-citizen also can be excluded if it is likely that he or she will become a "public charge." 32 In Lam Fung Yen v. Frick, ${ }^{33}$ the Sixth Circuit held that the petitioner could be denied entry because he planned to make his living by illegal gambling and therefore was likely to become a public charge:

[I]n United States v. Williams[, 175 F. 274, 275 (S.D.N.Y. 1910)], the term "persons likely to become a public charge" is construed as including, "not only those persons who through misfortune cannot be self-supporting, but also those who will not undertake honest pursuits, and who are likely to become periodically the inmates of prisons." We think this a reasonable construction. "A statute excluding paupers or persons likely to become a public charge is manifestly one of police and public security." [Kaoru Yamataya v. Fisher, 189 U.S. 86, 97 (1903).] Inmates of jails and prisons are for the time being public charges, and we think it open to conclusion by reasonable minds that those who will not work for a living, but rely for that purpose upon gambling, are more likely than citizens following the ordinary pursuits of industry to become, at least intermittently, public charges.

Such conclusion does not involve the proposition that gambling in any and every form is necessarily immoral; but public policy generally, as disclosed in statutes of varying nature, regards professional gambling at least as within the domain of police supervision and public security. ...

We therefore conclude that it was open to the Secretary of Labor to find that petitioner was at the time of his entry into the United States a person "likely to become a public charge," [and] excluded by ... the Immigration Act. . . ${ }^{34}$
This rather strained construction of the statute was rejected by the Ninth Circuit in Ng Fung Ho v. White: ${ }^{35}$

Lui Yee Law was arrested on departmental warrant dated February 16, 1918. ... He had originally entered in 1915 as a merchant. . . . He was arraigned, had a hearing, was represented by counsel, and in due course was ordered deported, and warrant issued. In a judicial proceeding, had some time before the present proceeding, it was held that, although the mercantile status of the alien when he entered the United States had not been successfully challenged, nevertheless there was evidence to sustain the Department of Labor in holding that the man was a gambler, and had been a gambler for some months before his arrest, and thus the question was raised whether he was a person likely to become a public charge. The evidence tended to show that about January, 1918, the alien lived in Texas, where he was a professional gambler; that about that time he was arrested in a gambling room; that he pleaded guilty to the charge of gambling and was fined \$25. . . [U]pon the evidence we are unable to find that the alien was likely to become a public charge at the time he entered the United States. Having entered in 1915 . . and not having been a public charge, we cannot see that an arrest in January, 1918, and a plea of guilty, and the payment of a fine of $\$ 25$ tend to prove that the alien had criminal tendencies when he arrived in the United States, or was likely to become a public charge. . . ${ }^{36}$

Later cases of this sort do not exist. This is because the public charge exception has fallen into disuse in modern times. ${ }^{37}$ As a result, the conflict created by Lam Fung Yen and $\mathrm{Ng}$ Fung Ho remains unresolved.

\footnotetext{
${ }^{32}$ See 8 U.S.C. § 1182(a)(4)(A).

${ }^{33} 233$ F. 393 (6th Cir.), cert. denied, 242 U.S. 642 (1916).

${ }^{34} I d$. at $396-97$.

${ }^{35} 266$ F. 765 (9th Cir.), cert. granted, 254 U.S. 628 (1920), aff'd in part and rev'd in part on other grounds, 259 U.S. 276 (1922).
}

\footnotetext{
${ }^{36} I d$. at $768-69$.

${ }^{37}$ Recently, however, the Trump Administration has attempted to breathe new life into it. See New York v. U.S. Dep't of Homeland Sec., 969 F.3d 42 (2d Cir.), petition for cert. filed, Docket No. 20-449 (Oct. 7, 2020); Cook Cnty., Ill. v. Wolf, 962 F.3d 208 (7th Cir.), petition for cert. filed, Docket No. 20-450 (Oct. 7, 2020). See also Catherine S. Ramírez, Immigrants and the Wealth Test, N.Y. Times, Feb. 26, 2020, at A27.
} 


\section{Admission because of legal gambling}

Although illegal gambling typically will keep a noncitizen out of the United States, in at least three instances legal gambling can help him or her get admitted.

First, a foreign gambler who intends to play in legal games, and is highly skilled, may be able to qualify for an O-1A visa, which is available to non-citizens "with extraordinary ability in the sciences, arts, education, business, or athletics." 38 This provision currently is being used by various professional poker players. ${ }^{39}$

Second, a non-citizen working for a legal gambling business in a foreign country may be able to qualify for an L1-A visa, which permits intra-company transfers of qualified executives and managers. ${ }^{40}$

Third, a non-citizen who plans to invest substantial funds in a legal gambling business may be able to qualify for an E-2/EB-5 investor visa. ${ }^{41}$

\section{DEPORTATION}

Foreigners who break the law while living in the United States are subject to deportation. ${ }^{42}$ Exam- ples include: committing an act of moral turpitude within five years of admission, or within 10 years of becoming a lawful permanent resident; ${ }^{43}$ carrying out two separate crimes involving moral turpitude at any time; ${ }^{44}$ or perpetrating an aggravated felony at any time. ${ }^{45}$

In Matter of $S-K-C-,{ }^{46}$ the respondent argued that he had not committed a gambling crime because he merely had been a dealer in an illegal gambling establishment. ${ }^{47}$ In rejecting this assertion, the BIA wrote:

It is contended by counsel that the respondent was a mere employee at the Bataan Recreation Club and cannot be said to have been gambling if he did not handle the money nor receive any of the winnings. No authority is cited for the contention. We ... conclude that the salary received by the respondent as a dealer in the Bataan Recreation Club was income derived from gambling activities. $^{48}$

\begin{abstract}
${ }^{38} 8$ U.S.C. $\S 1153(\mathrm{~b})(1)(\mathrm{A})$.
${ }^{39}$ See Terrence Chan, Lawyer Links, LiveJournal (Nov. 10, 2010), https:// terrencechan.livejournal.com/355654.html (reporting that Dallas immigration attorney Steve Ladik "has acted as the attorney for about 20 players from other countries who are currently playing poker professionally in the United States."). In 2009, Hall of Fame Canadian poker player Daniel "Kid Poker" Negreanu became a lawful permanent resident after winning four World Series of Poker bracelets and two World Poker Tour titles. See Daniel Negreanu, Wiripedia: The Free ENCYCLOPEDIA, https://en.wikipedia.org/wiki/Daniel_Negreanu (under "Personal Life"). In 2016, Negreanu became a U.S. citizen. See Kevin Nielsen, Canadian Poker Star Becomes American to Vote Against Donald Trump, Global News (Mar. 12, 2016) https://globalnews.ca/news/2574593/canadian-poker-star-becomesamerican-to-vote-against-trump/.

In In re Petitioner, 2009 WL 1450808 (A.A.O. 2009), a South African lawyer sought to gain admission by claiming she had extraordinary abilities as an attorney. Among other matters, she pointed to the fact that she had served as the lead attorney in the case that resulted in the legalization of gambling in South Africa. Agreeing with the immigration judge, the AAO found that the awarding of gambling licenses did not constitute "a contribution of major significance to the petitioner's field of law." Id. at *4.

${ }^{40}$ See 8 U.S.C. $\$ 1153(b)(1)(C)$. In Matter of 5-C-USA Corp., 2018 WL 3036039 (A.A.O. 2018), and Matter of 5-U- Corp., 2019 WL 4954795 (A.A.O. 2019), an online gambling company wanted to transfer one of its foreign employees to the United States to serve as its local general manager, but its request was denied because the employee did not possess the necessary qualifications.

${ }^{41}$ See 8 U.S.C. $§ 1153(\mathrm{~b})(5)$. The use of this provision to fund gambling enterprises is described in Glenn Light et al., EB-5 Financing of Resort Hotel Casinos, CASINO Enter. Mgmt., July 2013, at 18, available at https://www.lrrc.com/files/Uploads/ Documents/LightRutledge_0713.pdf.

In Tocara Invs. v. Johnson, 2017 WL 985644 (D. Nev. 2017), a Canadian citizen was denied an investor visa because he could not prove that his funds came from legitimate sources. Although he claimed his money was "from gambling winnings, [the] USCIS reasonably determined that Minci failed to prove this fact [because] Minci's tax returns indicated that he gambled away most of his 'winnings.'" $I d$. at *4. In Matter of P-A-S-, LLC, 2017 WL 6603966 (A.A.O. 2017), the company's participation in the EB-5 program was threatened after its principal "withdrew investor
\end{abstract}

funds [and improperly used them] at gambling establishments around the country." Id. at $* 4$.

${ }^{42}$ See 8 U.S.C. $\S 1227$. Even where deportation is not threatened, a non-citizen with gambling convictions can suffer other consequences. In In re Applicant, $2009 \mathrm{WL}$ 1742959 (A.A.O. 2009), for example, the applicant's request to adjust her status to permanent resident was denied because she had three misdemeanor gambling convictions. See also In re Applicant, 2009 WL 1450635 (A.A.O. 2009) (same result on nearly identical facts).

${ }^{43}$ See 8 U.S.C. $\S 1227(\mathrm{a})(2)(\mathrm{A})(\mathrm{i})$. The act must be punishable as a felony. Id

${ }^{44}$ See 8 U.S.C. $\S 1227$ (a)(2)(A)(ii). The two crimes cannot arise "out of a single scheme of criminal misconduct," but they can be charged "in a single trial." Id. For a case rejecting a gambler's claim that his various crimes fell within the "single scheme" exemption because they all had the same goal — to get him out of debtsee Matter of Vosganian, 12 I. \& N. Dec. 1 (B.I.A. 1966)

${ }^{45}$ See 8 U.S.C. $\$ 1227$ (a)(2)(A)(iii). In Vella v. Att'y Gen. U.S., 742 F. App’x 623 (3d Cir. 2018), the petitioner's order of deportation, based on his 2015 guilty plea to a charge of extortion, was upheld. As the court noted, an earlier attempt to deport him for illegal gambling failed:

Vella, a native and citizen of Italy, was admitted to the United States as a lawful permanent resident ("LPR") in 1967, at age twelve. In 2007, he was convicted of conspiracy to operate an illegal gambling business in violation of 18 U.S.C $\S 371$ and was sentenced to four months' imprisonment. Two years later, the Department of Homeland Security ("DHS") charged him with removability under 8 U.S.C. $\S 1227(\mathrm{a})(2)(\mathrm{A})(\mathrm{iii})$, as an alien convicted of an aggravated felony offense. He was subsequently granted adjustment of status.

Id. at 624 .

${ }^{46} 8$ I. \& N. Dec. 185 (B.I.A. 1958).

${ }^{47} I d$. at 187.

${ }^{48} I d$. For another such case, see Yee Look v. Burnett, 65 F.2d 594, 594 (9th Cir. 1933) (finding it sufficient "that the alien at and for about a week before his arrest was employed in a gambling resort[.]"). 
In Rong Chen v. Holder, ${ }^{49}$ the petitioner ran an illegal internet café in China. ${ }^{50}$ When the Chinese government sought to arrest him, he fled to the United States. ${ }^{51}$ Upon learning of his presence, the U.S. government began deportation proceedings ${ }^{52}$ and the petitioner sought asylum. ${ }^{53}$ In rejecting his request, the Fifth Circuit explained:

Chen first argues that he faces persecution for his membership in a social group which he identifies as "the internet gaming community." To be eligible for asylum, however, the social group "must share a common immutable characteristic that they cannot change or should not be required to change because it is fundamental to their individual identities or consciences." Mwembie v. Gonzales, 443 F.3d 405, 414-15 (5th Cir.2006) (internal quotation marks and citation omitted). Chen presented no evidence that membership in the online gaming community is so fundamental to one's identity or conscience that it functions as an immutable characteristic. Indeed, Chen was primarily involved with internet gaming as a means of employment, and we have held that one's occupation is normally not so fundamental that it can be considered immutable. Id. at 415 . Chen also argues that he was subject to persecution for his political opinions, but he has not offered any evidence that he was singled out for any political views. To the contrary, there is substantial evidence to support the IJ's determination that Chen's café was seized because it was engaged in unlawful gambling and because it was using pirated computer software. Chen fails to identify any persecution by the Chinese government except for the closing of his illegal business.

The record supports the IJ's conclusion that Chen was not persecuted on account of political opinion or membership in any protected group, but because he was running an illegal business. And because Chen did not establish grounds for asylum, it follows that Chen also cannot meet the more stringent burden for withholding of removal. $^{54}$

\section{A. Moral turpitude}

Courts generally do not view illegal gambling as a crime involving "moral turpitude." 55 In United States v. Carrollo, ${ }^{56}$ for example, the court explained:

This alien has received three sentences of imprisonment for a year or more for these offenses: (1) Perjury, in violation of Section 231, Title 18, U.S.C., 18 U.S.C.A. § 231; (2) Mailing a letter concerning a lottery, in violation of Section 336, Title 18, U.S.C., 18 U.S.C. A. $\S 336$; (3) Attempting to evade a tax, in violation of Section 145(b), Title 26, U.S.C., 26 U.S.C.A. $\S 145(b)$. . .

We are not prepared to rule that writing a letter concerning a lottery, even for the purpose of selling an interest in it, is an act of "baseness, vileness or depravity." On the contrary we think it would be ridiculous to say it is such an act. Even conducting a lottery is not such an act. Churches and states have conducted lotteries and they do so now where laws do not prohibit lotteries. ${ }^{57}$

More recently, in United States v. Chu Kong Yin ${ }^{58}$ the Ninth Circuit wrote:

The government first argues that gambling is a crime of moral turpitude. The record of conviction for Chu's gambling offense merely states that he was convicted under section 6, ch. 148 of the Hong Kong Laws. This section provides:
${ }^{49} 395$ F. App'x 93 (5th Cir. 2010).
${ }^{50} I d$. at 94.
${ }^{51} I d$.
${ }^{52} I d$.
${ }^{53} I d$.
${ }^{54} I d$. at 95 . For other such cases, see Evangelista v. Ashcroft, 81 F. App'x 695 (9th
Cir. 2003) (denying asylum to a petitioner who claimed he was forced to operate an
illegal casino in the Philippines); Fadul v. I.N.S., 210 F.3d 374 (Table), $2000 \mathrm{WL}$
302680 (7th Cir. 2000) (denying asylum to a petitioner who, while working in his uncle's casino in the Philippines, was targeted by armed rebels).

${ }^{55}$ For a critique of the current tests used to determine whether a crime involves moral turpitude, see Rob Doersam, Note, Punishing Harmless Conduct: Toward a New Definition of "Moral Turpitude" in Immigration Law, 79 Онго Sт. L.J. 547 (2018).

${ }^{56} 30$ F. Supp. 3 (W.D. Mo. 1939).

${ }^{57} I d$. at 6-7.

${ }^{58} 935$ F.2d 990 (9th Cir. 1991). 
Any person who gambles in a gambling establishment commits an offence and is liable on conviction to a fine of $\$ 10,000$ and to imprisonment for 3 months.

Hong Kong Laws, ch. 148, § 6. In support of its contention that gambling is a crime involving moral turpitude, the government cites dicta from Charles O. Finley \& Co., Inc. v. Kuhn, 569 F.2d 527 (7th Cir.), cert. denied, 439 U.S. 876.99 S. Ct. 214, 58 L.Ed.2d 190 (1978), which refers to "gambling, game-throwing or other conduct associated with moral turpitude" in discussing the power[s] of the Commissioner of Major League Baseball. Id. at 537.

The government also points to Chief Inspector Hawkesley's testimony that $\mathrm{Chu}$ hid under a table during a [Hong Kong] gambling raid and argues that $\mathrm{Chu}$ "displayed conscious knowledge of guilt of a morally undesirable crime." These arguments are not persuasive.... Moreover, the Board of Immigration Appeals has held that gambling offenses are not crimes of moral turpitude as that term is used in our immigration laws. See In re Gaglioti, 10 I. \& N. Dec. 719, 721 (1964) (“[T] he substantive crime or crimes involved in the gambling conspiracy charge do not involve moral turpitude."): In re G, 1 I. \& N. Dec. 59, 61-62 (1941) (because gambling is "not generally regarded as morally wrong or corrupt, as offensive to the moral sense as ordinarily developed," it is not a crime of moral turpitude). We find the Board's reasoning persuasive and hold that Chu's conviction for gambling is legally insufficient to support the conclusion that he was convicted of a crime involving moral turpitude. ${ }^{59}$

In In re Dimopoulos, ${ }^{60}$ however, the respondent was ordered deported $^{61}$ after pleading guilty to both racketeering and conducting an illegal gambling business. ${ }^{62}$ When he challenged the order, the BIA dismissed his appeal. ${ }^{63}$ The respondent then moved for reconsideration, which the BIA denied. ${ }^{64}$ In explaining its reasoning, the BIA wrote:

Public bribery under the pertinent Louisiana statute involves the "giving or offering to give, directly or indirectly, of anything of apparent... value" to any public officer, public employee, or person in a position of public authority if the item of value is given "with intent to influence the public official's... conduct in relation to his position, employment, or duty." See Louisiana Revised Statute Title 14 , section 118. Bribery offenses, like the foregoing have generally been deemed to involve moral turpitude, while illegal gambling activities have not. See Matter of Gaglioti, 10 I\&N Dec. 719 (BIA 1964) (finding gambling is not a crime involving moral turpitude); Matter of $H-, 6$ I\&N Dec. 358, 361 (BIA 1954) (finding bribery to be a crime involving moral turpitude); Matter of $V-, 4$ I\&N Dec. 100, 101-02 (BIA 1950) (same). Therefore, in the absence of evidence clearly establishing whether the gambling activity, the bribery, or both supported the racketeering charge, the respondent has not provided sufficient evidence to demonstrate that he has not been convicted of a crime involving moral turpitude. . . ${ }^{65}$

While gambling ordinarily is not a crime involving moral turpitude, it becomes one when it involves fraud:

The record reflects that during the period 1988 1997, the Applicant had multiple convictions under section 330 (gambling) and section 332 (obtaining money by gaming fraud) of the California Penal Code (PC). The Applicant was also convicted of theft under 484(a) PC in 1993. We find the Applicant's convictions under

\footnotetext{
${ }^{59} I d$. at 1003-04. In addition to $G$ - and Gaglioti, the BIA also found that gambling is not a crime of moral turpitude in Matter of S-, 9 I. \& N. Dec. 688, 696 (B.I.A. 1962): "The special inquiry officer found that gambling and owning and operating a gambling establishment and being a common gambler under sections 970 and 973 of the New York Penal Code are not crimes involving moral turpitude. We agree. ..." The AAO has reached the same conclusion in numerous cases, including: In re Applicant, 2009 WL 1742846, at *2 (A.A.O. 2009) (citing Gaglioti); In re Applicant, 2008 WL 5063583, at *2 (A.A.O. 2008) (also citing Gaglioti); In re Application, 2008 WL 4968645, at *2 (A.A.O. 2008) (citing $G$-); In re Application, 2008 WL 4052447, at *2 (A.A.O. 2008) (citing $S$ - and Gaglioti).

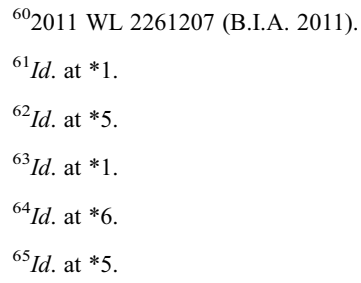


section 332 PC and 484(a) PC to be for crimes involving moral turpitude. The Ninth Circuit Court of Appeals[] addressed the issue of whether a violation of Cal. Penal Code $\S 484$ constitutes a crime involving moral turpitude in Castillo-Cruz v. Holder, 581 F.3d 1154, finding that a conviction for theft (grand or petty) under the California Penal Code requires the specific intent to deprive the victim of his or her property permanently and is, therefore, a crime involving moral turpitude. With regard to the Applicant's convictions for obtaining money by gaming fraud, the U.S. Supreme Court in Jordan v. De George concluded that "Whatever else the phrase "crime involving moral turpitude may mean in peripheral cases, the decided cases make it plain that crimes in which fraud was an ingredient have always been regarded as involving moral turpitude... Fraud is the touchstone by which this case should be judged. The phrase 'crime involving moral turpitude' has without exception been construed to embrace fraudulent conduct." 341 U.S. 223, 232 (1951). The Applicant does not contest that he has been convicted of crimes involving moral turpitude. $^{66}$

Although the issue has not yet been judicially decided, illegal gambling that involves the exploitation of animals almost certainly constitutes a crime involving moral turpitude. ${ }^{67}$

\section{B. Aggravated felony}

In Blake v. Carbone, ${ }^{68}$ the Second Circuit observed:

While a number of aggravated felonies require intentional conduct, not all are inherently base and vile. Two or more gambling offenses, for instance, may render a lawful permanent resident deportable for having committed an aggravated felony, see 8 U.S.C. § 1101(a)(43)(J), but the BIA has held that gambling is not a crime involving moral turpitude, see In the Matter of G-, 1 I. \& N. Dec. 59 (B.I.A.1941). Crimes involving moral turpitude and aggravated felonies are two broad classes of criminal conduct. Were we to conclude that such breadth signaled congruency, we would be extending the scope of [the immigration laws] to a potentially different, and perhaps much larger, class of persons than necessary. . . . ${ }^{69}$

Because of the wording of $\S 1101(\mathrm{a})(43)(\mathrm{J})$, only racketeering and gambling-related offenses fall within its purview. In Quinteros v. Attorney General of the United States, ${ }^{70}$ for example, the petitioner, while a member of the gang MS-13, helped to threaten several members of a rival gang. ${ }^{71}$ After pleading guilty to conspiracy to commit assault with a dangerous weapon and serving his sentence, the government sought to deport him on various grounds. ${ }^{72}$ In rejecting the government's inclusion of $\S 1101(\mathrm{a})(43)(\mathrm{J})$ in its charges, the Third Circuit wrote:
${ }^{66}$ Matter of I-H-C-, 2016 WL 8316072, at *2 n.1 (A.A.O. 2016). See also Matter of Scherbank, 10 I. \& N. Dec. 522, 523-25 (B.I.A. 1964) (because lawful permanent resident went to Canada to engage in "cheating at play," exclusion was appropriate); In re Applicant, 2014 WL 3898965, at *3 (A.A.O. 2014) ("The director noted that although running an illegal gambling scheme has been found not to involve moral turpitude, the separate offense of cheating at a legal gambling game does involve fraud and moral turpitude. . . . Consequently, the director's decision to deny the application on these grounds will be affirmed.").

${ }^{67}$ In In re Applicant, 2015 WL 1305711 (A.A.O. 2015), the applicant was found deportable because of his marijuana conviction. Id. at *3-*4. In a footnote, however, the AAO added:

The record further indicates that in 2003, the applicant was arrested under New York Agricultural and Markets Law \$351, prohibition of animal fighting, and New York Penal Law \$225.05, promoting gambling in the second degree. The record indicates that the applicant was convicted on a plea of guilty, and sentenced [to] probation for a term of three years. As the applicant is inadmissible under section 212(a)(2)(A)(i)(II) of the Act, we find it is unnecessary to examine whether the applicant is further inadmissible under section 212(a)(2)(A)(i)(I) of the Act for committing a crime involving moral turpitude.

$I d$. at * $1 \mathrm{n}$. 1 . Although the opinion does not provide any further details, it is likely that the applicant, who was from the Dominican Republic, was involved in cockfighting. See Katie Thomas, A Question of Culture: Dominicans Say Cockfighting is in Their Blood, N.Y. Times, Feb. 13, 2008, at D1 (explaining that "in the
Dominican Republic, cockfighting is celebrated as a symbol of the country's warrior spirit. Nearly every neighborhood and country village has a gallera, or cockfighting arena, and the sport is legal and regulated.").

In Matter of Ortega-Lopez, 27 I. \& N. Dec. 382 (B.I.A. 2018), a non-citizen was ordered deported for cockfighting. The opinion does not mention whether gambling was involved. As has been explained elsewhere, however, cockfighting almost always involves gambling:

Gambling is the norm at cockfights. Thousands of dollars can exchange hands as spectators and animal owners wager large sums on their favorite birds. The owners of birds who win the most fights in a derby (a series of cockfights) may win tens of thousands of dollars of presumably unreported income. Firearms and other weapons are common at cockfights, mainly because of the large amounts of cash present.

Cockfighting Fact Sheet, Humane Society of the United States, https://www. humanesociety.org/resources/cockfighting-fact-sheet.

${ }^{68} 489$ F.3d 88 (2d Cir. 2007).

${ }^{69} I d$. at 103 .

${ }^{70} 945$ F.3d 772 (3d Cir. 2019).

${ }^{71}$ Id. at 777 .

${ }^{72}$ Id. at $777-78$. 
Quinteros's conviction for conspiracy to commit assault with a dangerous weapon is not an aggravated felony as defined in $\S 1101$ (a) (43)(J). Subsection J makes an aggravated felony any offense described in 18 U.S.C. $\S \S$ 1084, 1955, or 1962. Sections 1084 and 1955 deal only with gambling-related offenses - for which Quinteros's conviction cannot be a categorical match. This leaves offenses described in 18 U.S.C. $\S 1962$, which fall under the general category of racketeering offenses. Although Quinteros's statute of conviction for conspiracy to commit assault with a dangerous weapon bears the title of "violent crimes in aid of racketeering activity," § 1959 (a)(6) has little in common with the offenses in $\S 1962$. . $^{73}$

Similarly, in In re Yunguang Zhang, ${ }^{74}$ the respondent was convicted of money laundering (18 U.S.C. § 1956), but the immigration judge decided he could be deported for violating 18 U.S.C. $§ 1955$ because the laundered money came from illegal gambling. ${ }^{75}$ In disagreeing, the BIA wrote:

In the case before us, we do not have a situation in which the respondent's conviction was for a crime that is "similar to" an offense under $18 \mathrm{U}$. S.C. $\S 1955$. The prohibition on money laundering found at 18 U.S.C. $\S 1956$ is completely different from the prohibition on illegal gambling businesses found at 18 U.S.C. $\S 1955$. If this were not the case, there would be no reason to have two separate and distinct sections in the federal criminal code.

Accordingly, we will sustain the respondent's appeal from the Immigration Judge's decision insofar as the Immigration Judge found the respondent was convicted of an aggravated felony under section 101 (a)(43)(J) of the INA. . . . ${ }^{76}$

Section 1955 defines an "illegal gambling business" as one that "involves five or more persons ... and ... has been or remains in substantially continuous operation for a period in excess of thirty days or has a gross revenue of $\$ 2,000$ in any single day." 77 In In re Calderon-Figueroa,${ }^{78}$ the respondent was ordered deported after an Arkansas state court found him guilty of running an illegal gambling house. ${ }^{79}$ Because the Arkansas statute did not include the scope and size provisions contained in $\S 1955$, the respondent argued he had not committed an aggravated felony. ${ }^{80}$ The BIA disagreed:

The respondent asserts that his conviction under ARK. CODE ANN. § 5-66-103 does not qualify as an aggravated felony because the Arkansas statute is broader than 18 U.S.C. $\S 1955$ and because the record of conviction contained in the administrative record does not reflect that his particular conviction was for an offense that involved the operation of an "illegal gambling business" within the meaning fo [sic] 18 U.S.C. $\S 1955(b)(1) \ldots$

As applied to this case, we conclude that the Arkansas offense of operating a gambling house in violation of ARK. CODE ANN. §5-66-103 is "an offense described in" 18 U.S.C. $§ 1955$ because all the conduct punishable under that statute-whether it be operating a gambling house directly, exhibiting and setting up gambling devices, or furnishing the financial resources for maintaining such a house or devices - would entail the "conducting" of a gambling business within the meaning of section 1955(a). As the Fifth Circuit has explained, one "conducts" an illegal gambling business within the meaning of 18 U.S.C. $\S 1955$ (a) by performing any necessary function in the gambling operation, other than that of a mere bettor. United States v. Avarello, 592 F.2d 1339, 1349 (5th Cir.), cert. denied, 444 U.S. 844 (1979). Accordingly, we find no reversible error in the Immigration Judge's determination that the respondent's conviction under ARK. CODE ANN. § 5-66103 renders him removable as an alien convicted

\footnotetext{
${ }^{73} I d$. at 785 .

${ }^{74} 2005$ WL 3952739 (B.I.A. 2005)

${ }^{75} I d$. at $* 2$.

${ }^{76} I d$. at *3.
}

\footnotetext{
${ }^{77} 18$ § U.S.C. 1955(b)(1)(ii)-(iii).

${ }^{78} 2006$ WL 1558706 (B.I.A. 2006)

${ }^{79} I d$. at ${ }^{*} 1$.

${ }^{80} I d$. at $* 2$.
} 
of an aggravated felony within the meaning of section 101(a)(43)(J). ${ }^{81}$

In Sanchez v. United States Citizenship and Immigration Services, ${ }^{82}$ however, a district court reached the opposite conclusion. Sanchez was convicted under California's illegal gambling house statute. ${ }^{83}$ Subsequently, he sought to become a naturalized citizen, but his application was rejected. ${ }^{84}$ When he challenged this decision, the government moved for summary judgment. ${ }^{85}$ In denying the motion, the court wrote:

It is not clear from the face of 18 U.S.C. $\S 1955$ that the limitations on the size and scope of the operation at issue are "purely jurisdictional." . . . Congress knows how to state a simple "interstate commerce nexus" element to a federal crime-examples abound in Title 18. That it chose not to do so suggests that it meant more to the size and scope elements in $\S 1955$ than a simple jurisdictional concern. Indeed, the legislative history of $\S 1955$ is clear that it was meant to apply only to "illegal gambling of major proportions" and does not apply "to gambling that is sporadic or of insignificant proportions." H.R. Rep. No. 91-1549, 1970 U. S.C.C.A.N. 4007, 4029. . .

There is also reason to believe that Congress intended to substantively limit the definition of an "aggravated felony" by importing the size and scope elements of $\S 1955$ into 8 U.S.C. $§ 1101$ (a) (43). Congress has specifically limited other defined aggravated felonies to violations of certain statutes where loss was over a certain amount. ... Also, the legislative history of $\S$ 1101(a)(43) shows that Congress intended to limit aggravated felonies to "only the most serious crimes" and intended to define "certain gambling offenses" as aggravated felonies. H.R. Rep. No. 104-22 (1995). . . .

All of these considerations lead to a conclusion that the size and scope elements of 18 U.S.C. $\S$ 1955 should not be disregarded and that a violation of California Penal Code $\S 337 \mathrm{a}(1)$ is not categorically an aggravated felony. The motion for summary judgment is DENIED. ${ }^{86}$

\section{CITIZENSHIP}

To become a naturalized American citizen, an applicant must demonstrate: (1) continuous residence in the United States "for at least five years and during the five years immediately preceding the date of filing" of his or her application for citizenship; (2) continuous residence within the United States "from the date of the application up to the time of admission to citizenship"; and, (3) "good moral character, attach[ment] to the principles of the Constitution of the United States, and ... dispos[ition] to the good order and happiness of the United States. ${ }^{.87}$

Three relatively old cases have considered whether an applicant should be denied citizenship because his or her gambling activities demonstrate a lack of good moral character. ${ }^{88}$ In each, the petitioner lost.

In In re Vouraxakis, ${ }^{89}$ the court explained:

There is no record of his employment for 24 years after he arrived in the United States. He was a partner in a restaurant in Wilkes-Barre, Pennsylvania, for about seven months from 1944 to 1949 . He stated that from 1927 to 1941 , while he was unemployed, his only income was from betting on horse races and prize fights and card games. He was arrested on gambling charges on three occasions, the last within five years prior to the filing of the petition, and paid fines. He was
${ }^{81} I d$. at $* 2, * 4$.
${ }^{82} 2014$ WL 12570172 (C.D. Cal. 2014).
${ }^{83} I d$. at * 1.
${ }^{84} I d$.
${ }^{85} I d$.
${ }^{86} I d$. at $* 2-3$.
${ }^{87} 8$ U.S.C. $\S 1427$ (a).
${ }^{88}$ It should be noted that filing an application for citizenship triggers a new
background check, which can result in an order of removal. In the Dimopoulos case discussed supra notes 60-65 and accompanying text, for example, Dimopoulos's 2004 application for citizenship led the government to take a fresh look at his 1980 gambling conviction and, based on it, begin removal proceedings. See Dimopoulos v. Blakeway, 2007 WL 922224 (S.D. Tex.), reconsideration denied, 2007 WL 1052551 (S.D. Tex. 2007). See also Zekic v. Rodriguez, 2015 WL 12751505, at*1 (W.D. Tex. 2015) (declining to consider the petitioner's application for citizenship after learning that he was in the middle of removal proceedings based on "his Texas state-court convictions for gambling promotion, keeping a gambling place, and possession of a gambling device. ...").

${ }^{89} 115$ F. Supp. 164 (M.D. Pa. 1953) 
never in the armed forces of the United States and never in industry at any time. He supported himself by gambling and borrowing money from friends. He has never contributed anything of any kind to the welfare of the United States. He resided in the United States for approximately 37 years before he petitioned to become a citizen. The road to citizenship is not spectacular but it is slow, dull day-by-day plugging, and without glory. It is working with your hearts, with your hands and with your minds, and loving your neighbor as yourself. It is loving America and obeying its laws. This petitioner has failed to meet the test required of a person applying for citizenship in the United States, and his petition will be denied by an appropriate order. ${ }^{90}$

In Petition of Reginelli, ${ }^{91}$ the New Jersey Supreme Court, disagreeing with the trial court, also held that the petitioner lacked good moral conduct because of his gambling:

It was established in a prior application and so found by the federal District Court in 1949 that Reginelli's only source of income then was from gambling. His prior criminal activities and record, plus his unsatisfactory explanation of his present sources of income, under these circumstances, compel the conclusion that his large, otherwise unexplained income during the period into which we are inquiring was still derived from the same illegal gambling activities.

His attempted explanation of the sources of his income, i.e., that he earned it from wagering on race horses, was incredible, especially in view of his inability to recall the name of a single horse on which he had won a large sum of money during the preceding five years, although he at times bet thousands of dollars. . . .

Our conclusions are in accord with those reached by the examiner, and we find that the respondent has failed to prove good moral character as required.

The judgment below granting citizenship is reversed and the petition is denied. ${ }^{92}$

Lastly, in Petition of Lee Wee,$^{93}$ the petitioner argued that the government's refusal to grant him citizenship based on where his gambling took place was unconstitutional. ${ }^{94}$ In rejecting this contention, the court wrote:

While the petitioner admits at least four convictions for violation of the Los Angeles City Ordinance prohibiting gambling during that period, he, nevertheless, contends that he is entitled to admission as a citizen because Subdivision 5 of Section 1101(f) of Title 8, U.S.C.A., Sec. 101(f) (5), Immigration and Nationality Act, is unconstitutional in that (1) it does not provide a 'uniform Rule of Naturalization,' and (2) it is in violation of the due process clause of the Constitution, U.S.C.A.Const. Amend. 5. . . .

[I] conclude that subdivision 5 of Section 1101 (f), being uniformly of geographical applicability, is not unconstitutional, even though a person who lives in Gardena, California, where gambling is permitted, might be entitled to be naturalized, whereas the same acts committed in Los Angeles might result in lawful arrest and denial of citizenship. . . .

The petition for naturalization of Lee Wee will be denied on the ground that petitioner has failed to establish good moral character during the period required by law in that he has in fact been convicted of more than two gambling offenses during the requisite five year period. ${ }^{95}$

\section{DENATURALIZATION}

It is extremely rare for a person who has gained U.S. citizenship to have it revoked. ${ }^{96}$ However, if the person procured his or her citizenship through fraud, the

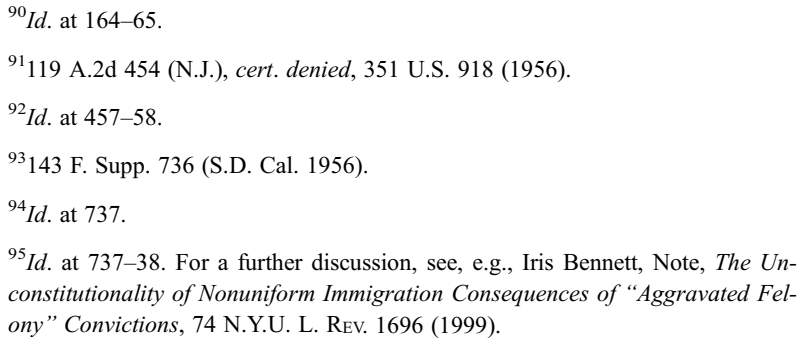

${ }^{95} I d$. at $737-38$. For a further discussion, see, e.g., Iris Bennett, Note, The Unconstitutionality of Nonuniform Immigration Consequences of "Aggravated Felony" Convictions, 74 N.Y.U. L. REv. 1696 (1999).

${ }^{96}$ In 2020, however, the Trump administration announced plans to make revocations more common. See Katie Benner, Office of Denaturalization Is Established, N.Y. Times, Feb. 27, 2020, at A15 ("The Justice Department said Wednesday that it had created an official section in its immigration office to strip citizenship rights from naturalized immigrants, a move that gives more heft to the Trump administration's broad efforts to remove from the country immigrants who have committed crimes."). 
government can seek revocation. ${ }^{97}$ In United States v. Costello, ${ }^{98}$ for example, the Second Circuit ordered Mafia boss Frank Costello's citizenship revoked because his 1925 naturalization application had concealed his extensive criminal dealings, which included "engag[ing] in large-scale gambling operations[.]" 99 On appeal, however, the U.S. Supreme Court ordered the case dismissed because the government had failed to file an affidavit of good cause. ${ }^{100}$

\section{THE ROLE OF DISCRETION}

In deciding the cases that come before them, immigration officials have substantial discretion. ${ }^{101} \mathrm{Gam}$ bling crimes can push them towards, or away from, showing leniency. ${ }^{102}$

In Matter of De Lucia, ${ }^{103}$ the BIA wrote:

Counsel urges that the respondent's illegal gambling activities in 1962 furnishes no basis for the special inquiry officer's conclusion that the respondent is not a person of good moral character. While it is true that section 249 of the Immigration and Nationality Act, as amended, does not require an applicant for relief to establish good moral character for any specified period of time, nevertheless, we believe that an illegal $\$ 10,000$ bet on the World Series and an illegal $\$ 15,000$ wager on a prize fight in 1962 are factors properly considered by the special inquiry officer in reaching a conclusion as to

${ }^{97}$ See 8 U.S.C. $§ 1451$.

${ }^{98} 247$ F.2d 384 (2d Cir. 1957), rev'd, 356 U.S. 256 (1958).

${ }^{99} \mathrm{Id}$. at 385 .

${ }^{100}$ See Costello, 356 U.S. at 257 . Although the government refiled, its new case also was thrown out. See Costello v. I.N.S., 376 U.S. 120 (1964). For a further look at Costello's life, see George Wolf \& Joseph DiMona, Frank Costello: Prime MiNISTER OF THE UNDERWORLD (1974).

${ }^{101}$ In Matter of I-D-R-, 2017 WL 3837307 (A.A.O. 2017), for example, a noncitizen was found to be deportable. On appeal, however, he was permitted to remain because his removal was likely to upend his wife's recent recovery from a gambling addiction.

${ }^{102}$ Of course, there are some cases in which discretion cannot be exercised. See, e.g., Tahir v. Lehmann, 171 F. Supp. 589, 590 (N.D. Ohio 1958) (“At subsequent hearings, it appeared that petitioner had, during the period of 10 years last past, been convicted on six occasions of gambling offenses and on that account was unable to establish good moral character. . . "), aff'd mem., 264 F.2d 892 (6th Cir.), cert. denied, 361 U.S. 876 (1959); Matter of A-, 6 I. \& N. Dec. 242 (B.I.A. 1954) (refusing to stop respondent's deportation because he had been arrested seven times, including at least twice for gambling offenses). In In re Applicant, $1995 \mathrm{WL}$ 18235771 (O.A.A. 1995), the applicant's request to be admitted to the United States was turned down in part because: whether the respondent is a person of good moral character. ... The respondent, in fact, testified that for most of his life he has derived his income principally from betting on horse races.... According to the record his last profitable employment as the owner of a business was in 1922-1923 when he operated a restaurant. . . . We find no error on the part of the special inquiry officer in considering the respondent's illegal gambling activities as a factor in reaching a conclusion that relief is not warranted on this record. ${ }^{104}$

Similarly, in Matter of $N-M-B-M-,{ }^{105}$ the respondent's request for cancellation was denied. ${ }^{106}$ Although the AAO primarily based its decision on the respondent's failure to demonstrate extreme hardship, ${ }^{107}$ it also noted:

As the Director found, in 2007, the Applicant was convicted of aggravated bodily injury in the third degree in violation of New Jersey Statutes Annotated § 2C:12-1b(1) and was sentenced to two years of probation. In addition, in 2008, he was convicted of promoting gambling in violation of New Jersey Statutes Annotated $\S$ 2C:37-2A(2) and sentenced to two years of probation. The record further shows the Applicant was again convicted of promoting gambling in 2012, sentenced to three years of probation, and ordered to perform 100 hours of community service.
The record further reflects that the applicant has been arrested and convicted 18 times for illegal gambling between 1978 and 1991. Although his gambling convictions are not crimes involving moral turpitude, they are violations of local laws, which when considered in their totality over a 13 year period, show the applicant's inability to abide by those laws. Such inability to abide by specific laws does not support a showing of rehabilitation or that his admission would not be contrary to the welfare, safety, or security of the United States.

Id. at $* 2$.

See also Liu v. Ashcroft, 78 F. App'x 609, 609 (9th Cir. 2003) (“Feng's evasive responses at the deportation hearing to questions about her knowledge of the illegal gambling scheme to which she had pled guilty supported the IJ's 'decision to give [her] testimony 'very little weight[.]' See Sarvia-Quintanilla v. INS, 767 F.2d 1387, 1393 (9th Cir.1985).”).

${ }^{103} 11$ I. \& N. Dec. 565 (B.I.A. 1966), aff'd, 370 F.2d 305 (7th Cir. 1966), cert. denied, 386 U.S. 912 (1967).

${ }^{104}$ Id. at 574 .

${ }^{105} 2018$ WL 5298705 (A.A.O. 2018).

${ }^{106} I d$. at *3.

${ }^{107} I d$. 
We note that the Applicant and his spouse deny that he committed the actions which led to his conviction for aggravated bodily injury. In addition, he mentioned only this conviction in his waiver application, asserting that he had no other criminal record. However, as noted above, the Applicant was also convicted in 2008 and 2012 for promoting gambling. His failure to take responsibility for his actions and entire criminal record would weigh heavily against the favorable exercise of discretion. ${ }^{108}$

In In re Anastasiadis, ${ }^{109}$ the respondent was ruled deportable after completing a 38-month sentence for federal racketeering. ${ }^{110} \mathrm{He}$ also had two gambling convictions. ${ }^{111}$ Nevertheless, the BIA cancelled his removal after finding that he had changed his ways:

The existence of a criminal record and its nature, recency, and seriousness bear directly on the respondent's undesirability as a permanent resident of the United States. . . The respondent's racketeering conviction for co-owning a gambling business is now 17 years old. He admitted pleading guilty to two other gambling-related offenses, but the record does not reflect that these offenses were serious in nature.... Furthermore, the respondent, who has not been in trouble with the law since 2000, testified that he recognized that he had a gambling problem and no longer goes to the gambling clubs. . . ${ }^{112}$

In the absence of actual proof, the failure of officials to show leniency in a gambling case is likely to be countermanded. ${ }^{113}$ In Rassano v. Immigration and Naturalization Service, ${ }^{114}$ the government sought to deport the petitioner because of his alleged involvement in gambling and prostitution. The Seventh Circuit, however, found the government's suspicions insufficient:

In its concluding presentation to us on this appeal the Service notes that petitioner has had no difficulty with the law in recent years, yet urges that highly credible evidence links him to gambling and prostitution through his employment and investments. It then immediately follows with the Board's statement that petitioner "is also an acknowledged close associate of Joseph Aiuppa, whose leading position in gambling, prostitution and other forms of vice in the Cicero[, Illinois] area is well established in this record."

We have no brief for Mr. Aiuppa nor do we hold up petitioner as a model of exemplary conduct. However, it has become crystal clear to us that the thread which holds this fabric together is

\footnotetext{
${ }^{108} I d$. at *2-*3 nn.1-2. For another such case, see In re Self-Petitioner, 2014 WL 7793550 , at *8 (A.A.O. 2014) ("The petitioner's concealment of his arrests, and his failure to discuss the circumstances surrounding his arrests and his conviction for a gambling related offense, reflect negatively on his moral character.").

${ }^{109} 2008$ WL 5537745 (B.I.A. 2008).

${ }^{110} I d$. at $* 1$.

${ }^{111} I d$.

${ }^{112} I d$. at $* 2$

${ }^{113}$ But see Cho v. Ashcroft, 76 F. App'x 184, 184 (9th Cir. 2003) (“"Cho moved to continue removal proceedings until the outcome of his wife's application for adjustment of status. The IJ denied the motion after considering the nature of the requested relief, the likelihood of hardship to Cho's family, and Cho's alleged involvement in illegal gambling. Based on this record the IJ did not clearly abuse its discretion by denying Cho's motion for a continuance.").

It is, of course, incumbent on the applicant to produce all pertinent records, including copies of any gambling arrests or convictions:
}

We sent the Applicant a request for evidence (RFE), as a Federal Bureau of Investigation report based upon his fingerprints indicated that he was found guilty at trial for misdemeanor minor gambling under section 463.350 of the Nevada Revised Statutes in [] 2000. . . We requested court documentation indicating the disposition[] of the Applicant's misdemeanor minor gambling ... offense[].

In response, the Applicant submits the results of a criminal history check from the [] Metropolitan Police Department. This police department record does not contain any information regarding the . . quer[y] in our RFE. In addition, the Applicant did not submit, as requested, court documentation ... indicating the disposition[] for the aforementioned arrest[].

Accordingly, the Applicant . . . is also ineligible [to remain in the country] b. ecause of his failure to provide information necessary for the adjudication of his application. See 8 C.F.R. $\S$ 103.2(b)(14), 244.9(a).

Matter of F-L-R-, 2017 WL 2573408, at *4 (A.A.O. 2017). See also In re Applicant, 2009 WL 6701142 (A.A.O. 2009) (dismissing applicant's appeal because he did not supply information regarding, among others things, his 1991 and 1992 arrests for promoting gambling).

In In re Wan, 2003 WL 23269867 (B.I.A. 2003), the BIA decided that the respondent's alleged concealment of his gambling conviction could be ignored because it would not change the case's ultimate outcome:

We note that the DHS has attempted to submit evidence that the respondent lied on the stand when he testified that he had not been convicted of any crimes in the last year. . . The DHS suggests that the respondent was, in fact, convicted of Attempted Promoting of Gambling in the Second Degree a number of months before giving such testimony. . . . In most cases, our practice would be to deem the DHS's appeal to be a motion to remand to permit the Immigration Judge to consider the new evidence. . . . Because we sustain the DHS's appeal on other grounds, we need not grant the motion.

Id. at $* 2$ n. 2 .

In Plewa v. I.N.S., 77 F. Supp. 2d 905 (N.D. Ill. 1999), the applicant failed to disclose in her naturalization application that she once had been arrested for gambling. The court excused the omission after finding that the applicant had been told by an experienced immigration counselor "that the incident need not be disclosed." Id. at 912.

${ }^{114} 492$ F.2d 220 (7th Cir. 1974). 
inextricably comprised of fibers of hearsay and guilt by association. Such reeds are too slender for this cloth. ${ }^{115}$

In In re Ghulam, ${ }^{116}$ the BIA decided that the immigration judge had erred by ordering the respondent deported for, among other reasons, his alleged gambling problem:

Third, we find that the respondent has sufficiently explained why his wife's testimony suggests that she was unaware that a large portion of his income in 2004 was from gambling winnings (compare Tr. at 24 with 43). As the respondent indicated in his appellate brief, he testified that his wife did not initially know about his gambling (Tr. at 32). In addition, we note that $\$ 24,500$, which is the amount the respondent claimed to have won from gambling, is the amount indicated as other income on the original 2004 federal tax return under Exhibit 2a, Tab B, and on the amended tax return submitted on appeal. Therefore, we do not find that the record sufficiently supports the Immigration Judge's finding that the respondent's testimony concerning his 2004 income and tax returns was not credible. Further, we do not find that the record supports a finding that the respondent has a gambling problem. ${ }^{117}$

\section{CONCLUSION}

At times, the U.S. immigration system can resemble a giant casino. ${ }^{118}$ And as this article has shown, a lawyer who does not know its rules can do serious harm to his or her client. ${ }^{119}$
${ }^{115} I d$. at 226-27. In United States v. Sanchez-Espinoza, 343 F. App’x 254 (9th Cir. 2009), the Ninth Circuit, in a case with very different factual circumstances, also rejected the government's speculation:

[T]he district court plainly erred in finding that Sanchez smuggled at least one hundred aliens based on four smuggling incidents over five years and Sanchez's immense gambling losses. Such conjecture is insufficient to support application of a sentencing enhancement. See United States v. Eirven, 987 F.2d 634, 636 (9th Cir.1993). Rather, the district court was limited to an enhancement consistent with the evidence presented at trial, i.e., at least fifty-four aliens.

Id. at 257 .

${ }^{116} 2007$ WL 275781 (B.I.A. 2007)

${ }^{117} I d$. at $* 2$ (footnote omitted).

${ }^{118}$ See generally Dejan Gavrilovic, What Immigration and Gambling Have in Common and What It Has to Do with All of Us[], LCB (Mar. 11, 2019), https://lcb. $\mathrm{org} /$ news/editorials/what-immigration-and-gambling-have-in-common-and-whatit-has-to-do-with-all-of-us. In touting the annual Diversity Visa Lottery (8 U.S.C. § 1153(c)), one website exclaims:

Every year the United States gives away 55,000 US permanent resident cards (Green Cards) to winners of the Diversity Visa Lottery also known as Green Card Lottery. And the best part is: Almost everyone can participate! Apply now for the official US Green Card Lottery or check your result of the previous lottery-are you a winner?

Green Card Lottery, The AMERICAN DREAm, https://www.green-card.com/greencard-lottery/. For a further look at the diversity lottery, which is designed to admit persons from countries with low immigration rates to the United States, see Patrick Kennedy, The Labor Economics Case for the Diversity Visa Lottery, 71 Stan. L. Rev. Online 159 (2018).

The United States also annually holds a lottery for $65,000 \mathrm{H}-1 \mathrm{~B}$ visas, see 8 U.S.C. $\S 1184(\mathrm{~g})(1)(\mathrm{A})$, which allows recipients to temporarily work in the country. See
Emily C. Callan, Is the Game Still Worth the Candle (or the Visa)? How the H-1B Visa Lottery Lawsuit Illustrates the Need for Immigration Reform, 80 ALB. L. Rev. 335, 335 (2016-2017) (describing the H1-B lottery as "arguably the worst game ever invented by our government in the history of our country."). For a case in which a casino's cardroom manager was deemed ineligible for an H-1B visa because his position did not require any special skills, see In re Petitioner, $1996 \mathrm{WL}$ 33420392 (O.A.A. 1996). For a case reaching the opposite conclusion with respect to a casino's cardroom supervisor, see In re Petitioner, 1995 WL 1797683 (O.A.A. 1995).

The refugee asylum claims process also has been likened to gambling. See, e.g., Jaya Ramji-Nogales et al., Refugee Roulette: Disparities in Asylum Adjudication, 60 Stan. L. Rev. 295 (2007); Angela DeVolld, Note, Refugee Roulette: Wagering on Morality, Sexuality, and Normalcy in U.S. Asylum Law, 92 NeB. L. Rev. 627 (2014).

${ }^{119}$ Except, of course, in Hollywood, where there always is a happy ending. In the 1951 movie Gambling House (RKO Radio Pictures, Inc.), U.S. immigration officials begin deportation proceedings against gambler Marc Fury (Victor Mature) after he beats a murder rap. In exchange for $\$ 50,000$, Fury had stood trial for gangster Joe Farrow (William Bendix), who, during a crooked craps game, had killed one of the other players and wounded Fury to ensure Fury's cooperation. After Fury is acquitted, Farrow reneges on the deal, but Fury eventually manages to get Farrow to pay up. By now, however, Fury has learned from Lynn Warren (Terry Moore), a social worker he has become interested in romantically, that an immigrant family named the Sobieskis are about to be deported because they have lost their sponsor. Fury therefore gives the $\$ 50,000$ to Warren so that the Sobieskis can stay in the country. Fury then delivers an impassioned speech at his own hearing explaining why he wants to remain in the United States, which causes Judge Ravinek (Basil Ruysdael) to cancel Fury's deportation order. See Gambling House (1951), TCM, http://www.tcm.com/tcmdb/title/75929/Gambling-House/. See also Paul Magro, Media Portrayal-Movies, in 2 American Immigration: An ENcyclopedia of Political, Social and Cultural Change 384, 387 (James Ciment \& John Radzilowski eds. 2d ed. 2015) (commending Gambling House for shining a light on "the struggles of European refugees."). 